Article

\title{
An Empirical Study to Explore the Adoption of E-Learning Social Media Platform in Taiwan: An Integrated Conceptual Adoption Framework Based on Technology Acceptance Model and Technology Threat Avoidance Theory
}

\author{
Mei-Hui Peng ${ }^{1,2, *(D)}$ and Hsin-Ginn Hwang ${ }^{1}$ \\ 1 Institute of Information Management, National Yang Ming Chiao Tung University, Hsinchu 300, Taiwan; \\ hghmis@gmail.com \\ 2 Department of Information of Management, Minghsin University of Science and Technology, \\ Hsinchu 302, Taiwan \\ * Correspondence: clare4260@gmail.com
}

\section{check for} updates

Citation: Peng, M.-H.; Hwang, H.-G An Empirical Study to Explore the Adoption of E-Learning Social Media Platform in Taiwan: An Integrated Conceptual Adoption Framework Based on Technology Acceptance Model and Technology Threat Avoidance Theory. Sustainability 2021, 13, 9946. https://doi.org/10.3390/ su13179946

Academic Editor: Ashutosh Tiwari

Received: 30 June 2021

Accepted: 30 August 2021

Published: 4 September 2021

Publisher's Note: MDPI stays neutral with regard to jurisdictional claims in published maps and institutional affiliations.

Copyright: (c) 2021 by the authors. Licensee MDPI, Basel, Switzerland. This article is an open access article distributed under the terms and conditions of the Creative Commons Attribution (CC BY) license (https:// creativecommons.org/licenses/by/ $4.0 /)$.

\begin{abstract}
Currently, social media is ubiquitous and essential for social networking and content sharing. It is an effective platform for teaching and learning in higher education and provides a novel way to communicate between instructors and pupils. Thus, the purpose of this study was to present a research framework to examine students' motivation to adopt an e-learning system with social medial platforms. This cross-sectional study used the questionnaire to collect data from the students in Taiwan. A framework has examined students' motivation to adopt an e-learning system with social medial platforms based on the modified technology acceptance model (TAM) and technology threat avoidance theory (TTAT). The research framework was evaluated by structural equation modeling (SEM) and represented by Smart-PLS. A total of 262 valid responses were used for statistical analysis. The results recommended modified research model explains $77.0 \%$ of the variance of motivation to adopt $\left(R^{2}=0.77\right)$. The findings also supported perceived usefulness, perceived ease of use, perceived cost, perceived effectiveness, and self-efficacy significantly influenced students' motivation to use. Results also indicated threat appraisal, perceived susceptibility, and perceived severity are not significant factors for predicting students' motivation to adopt e-learning in higher education.
\end{abstract}

Keywords: social media; TTAT (technology threat avoidance theory); e-learning (electronic learning); sustainable

\section{Introduction}

Both knowledge and technology are the trends of the future development of society [1] Knowledge has become the key factor of economic development. Only through continuous learning and growth can we keep up with the times and create new opportunities in the knowledge economy. In the Web 2.0 era, social media has given us a platform for a new electronic learning (e-learning) environment [2]. As a result, the emergence of social media, sharing, and interaction have become important traits of e-learning [3,4].

Due to rapid development, e-learning has become a gradually fashionable method of learning in higher education institutions, following the speedy development of cyberspace technology. It has been completed in many university programs and is one of the new learning trends that challenge the principle of higher education [5]. E-learning is not intended to replace traditional classroom learning but offers a new channel for interaction and communication between teachers and students [6]. The recent technology infusion has caused participation and communication methods in traditional university classrooms to change [7]. In this study, it was explained that the use of e-learning is growing popular in many higher educational institutions or universities in Taiwan [8]. Nowadays, students 
must be prepared to prosper in a continuously developed technological landscape, thus can be competitive around the world [8].

The trend of e-learning has existed for many years. It has become critical in the light of the global impact of the COVID-19 outbreak sweeping across the world in 2020. In mid-May 2021, with the outbreak of COVID-19 in Taiwan, the government was forced to issue a policy that all educational institutions in Taiwan, from colleges and universities to preschoolers, would stay home to reduce activity and the chances of cluster infections. In order not to stop learning, e-learning was used to replace traditional classroom learning to reduce the risk of cluster infection. At the same time, it subverted the way of thinking and learning about e-learning in the meantime.

The educational environment has changed significantly in the last few decades. However, with the advancement of technology, the development of the Internet has increased very specific solutions for e-learning in the learning environment. Students can connect to e-learning courses through the Internet, and they can use a laptop, computer, etc., to attend the class. Thus, they do not need to attend face-to-face teaching to learn. Therefore, online education could reduce the risk during the COVID-19 pandemic.

E-learning has the advantage of learning anytime, anywhere. Especially, people can use the convenience of mobile data for e-learning. The time and place of learning are no longer limited by the traditional teaching methods that must accommodate the teacher's time and classroom location for transportation issues [9]. However, one of the more important aspects of e-learning's learning is whether students learn more effectively when they learn using online instruction than they do in the classroom [10]. On the other hand, the issue of suitability of teaching for educational e-learning refers to whether the use of information technology and the design of teaching techniques provide different levels of teaching content for each individual's characteristics, thus improving the e-learning effectiveness of learners [11]. This is another important key indicator of e-learning. On the contrary, e-learning is not a perfect teaching tool. It also causes some problems [12] that the teachers have more difficulties handling the e-learning situation in real-time and the personal interaction.

It is believed that e-learning can bring improvements to any process within social media operation and delivery. For instance, the cost savings that e-learning can bring to the mass media system is an important driver for the implementation of e-learning applications. A large part of these cost reductions stems from changing the mass media model from a reactive to a proactive approach. Improvement of technology reduces the cost of using the Internet, which improves users' interest to use social media. In this way, social media reaches the masses very easily and it can be considered as mass media. With the dramatically changing technological environment, social media platforms have become ubiquitous and play an important role in our daily lives [13]. As the Internet has matured, learning through the use of social media in education has become an indispensable part of our lives. Most teenagers have an account on any of the popular social media networks [14,15], such as Snapchat, Instagram, WhatApp, Facebook, Twitter, TikTok, and YouTube, etc. WhatsApp has raised the minimum age to 16 [16]. Social media is becoming increasingly popular in e-learning, and in higher education, social media platforms are providing a new channel and method of communication between teachers and students [17]. In seeking to understand how students approach learning, Laurillard [18] identifies a dialogic framework for learning, which is the interaction between teachers and students during the teaching and learning process. Social media has multiple levels of interaction in online instruction and promotes student participation and collaboration. The use of social media increases the effectiveness and persistence of formal learning, stimulates student engagement, and enhances the social aspects of e-learning [19]. Since the e-learning is not a face-to-face education, it may be less effective for learning, especially communication skills [19].

Students are using a variety of online instruments to meet different requirements. Social media and education go hand in hand in modern society because of the environment that created them [20]. The earliest incarnation of social media, primarily in the context 
of learning was introduced on the Web in 1973 by David R. Woolley [21]. Social media platforms offer features and functionality that can be used to complement the use of traditional classroom instruction and bridge the limitations of spatial differences. Given the power of social media tools such as Snapchat, Instagram, WhatsApp, Facebook, Twitter, TikTok, and YouTube to facilitate the dissemination and uptake of new and trending content, e-learning content creators and instructional designers can integrate them into the e-learning environment to successfully utilize social media for instruction in the curriculum, taking advantage of all the resources social media has to offer for discussion and ideasharing and networking. Teachers use social media not only to share links and resources but also to stimulate student interest and participation. They also aim to find the social media applications that produce the most interesting content in the shortest amount of time and reduce the amount of time spent in traditional classrooms [22]. Teachers use social media to encourage students to participate in discussions, webinars, and groups, and to ask them to provide feedback and generate new ideas.

The biggest advantage of social media is that it makes communication easier. Students can connect with anyone over the Internet at any time [23] but their private information can be leaked very easily. They can use such devices through a smartphone, tablet, or computer, and students can exchange questions, make phone calls or video calls. The educational benefits of social networking sites are also great for those who help students prepare for important classes and learn certain concepts. Social media platforms will contain the latest information on various school subjects, so students have the opportunity to investigate and research new things. Today, social media is a treasure chest for students. We are witnessing a new era of social media learning. We have two topics in this study: one is how much the effectiveness and persistence are increasing by social media platforms [11]. Another is why the students are not motivated to adopt social media platforms.

In [20], it is presented that many disadvantaged students are unable to obtain a formal education by attending a formal program at an education institution. These students could get help in social platforms. The purpose of using social media in e-learning is to make it easier for students to access the learning content they are looking for quickly and effectively.

The real power of social media in encouraging e-learning is in facilitating student learning. In the early 1990s, the development of e-learning instructional technology was still limited by the use of technology. However, as technology has advanced, technical problems have been overcome and e-learning has become more efficient gradually.

Motivation is an encouraging potency that escorts an individual toward a specific objective and points out an individual's feeling, willingness, and preparedness to engage in a positive behavior [24]. Additionally, students generally encounter a range of technical threats while they access several social groups or spend a lot of time on the Internet. As motivation illustrates the reasons why individuals engage in specific behaviors, it is also significant to consider the reasons and controls that impact an individual's motivation to engage in a specific social media platform [24].

The technology acceptance model (TAM) [25] presents perceived ease of use and perceived usefulness tests for application use. This research investigates the intent of TAM with students learning through e-learning and uses TAM as a hypothesis for the effect of these variables on the use of e-learning as a basis for learning effectiveness. The current study includes perceived easiness to use and usefulness to hypothesize that if students feel that a social media platform is easy to use and it is useful and effective for fulfilling their study purpose, then their motivation will be great to adopt it.

Technology threat avoidance theory (TTAT) [26] emphasizes students' motivation to adopt an e-learning platform to overcome their avoidance motivation intention. Technology threat avoidance theory is a broad-based theory that explains why and how individual IT users engage in threat avoidance behaviors. This study aims to employ the TAM and TTAT as a framework to provide a basis for using social medial platforms for students' motivation behavior and avoidance behavior in adopting efficient e-learning. 


\section{Theoretical Model and Hypothesis Development}

\subsection{E-Learning (Electronic Learning)}

E-learning is fundamentally the usage of computers and the Internet to transmit the practical abilities and awareness of the application and procedure of learning [27]. E-learning denotes a range of behaviors to pick up or train over the expertise of information technology. Information and communication systems, whether associated with the Internet or not, use precise media in the learning procedure devoid of uninterrupted human interaction. Regardless of developments in apparatus and prospectus, e-learning is still most often denoted as out-of-classroom or in-classroom teaching for understanding employing technology. E-learning denotes the usage of the Internet to provide training courses to students without the necessity to travel to a physical location, decreasing the inopportuneness of space, interval, and time for learners [27].

An e-learning platform is a medium for interactive communication between the instructor and the learners in a digital learning environment [27]. An e-learning platform is an environment that provides a medium for interactive communication between the instructor and the learner. The e-learning platform is a medium for interactive communication between instructors and learners in an e-learning environment, using the Internet to break through the limitations of time and space to synchronous or asynchronous teaching and learning activities in a variety of e-learning platforms, providing a medium for interactive communication between instructors and learners in an e-learning environment [28].

\subsection{Social Media}

The concept of social media has emerged in the Web 2.0 era [29]. A social medial platform is formed by a group of Internet users with common preferences through the Internet [30]. With the rapid development of social media, teachers and students are also using social media for information transfer or classroom interaction. In general, overall, social media can be considered as web-based platforms, can help students to share their information with others and help to interact with instructors as well other students during the learning [31]. In other words, social media are web-based applications, which can help the students to provide collective creation and information exchange. It has been observed that the most common social media used by teachers in teaching are Snapchat, Instagram, WhatsApp, Facebook, Twitter, TikTok, and YouTube [32], etc. Therefore, social media were included in this study as one of the comparison objects of e-learning platforms called social media teaching platforms. Therefore, social media were considered as social media teaching platforms from the current study perspective.

However, in the current changing environment, environmental influences will also affect people's behavioral intentions. Social media platforms, for example, have significantly changed the behavior of individuals [3]. Social media can save the cost which can help to reach the masses easily. In other words, social media can help to bring mass media together at a very affordable price and in a short amount of time, which can be considered as mass media. A large part of these cost reductions is due to changing the mass media model from the reactive approach of the past to an active one. Now, improvement of technology helps the social media to be more independent and also improve the security as human intervention becomes less and less. Thus, social media increasingly become mass media. This is because it requires less human intervention than traditional methods and is more secure. It plays an important role in the function of continuous monitoring, sending personalized messages, and keeping in touch.

\subsection{TAM (Technology Acceptance Model)}

In terms of the evolutionary development of behavioral theory, TAM was first proposed by Fred Davis in 1986 [25], primarily to measure people's willingness to accept and adopt new information technology innovations of the era, such as electronic mail systems. The model has two main factors that determine IT adoption: perceived usefulness and perceived ease of use. Davis [25] in his work defined them as the degree to which a person 
believes that using a particular system will improve his or her work performance and the degree to which a person believes that using a particular system will be easy to achieve. Davis [25] reported that the relationship between perceived usefulness and adoption is significantly stronger than the relationship between perceived ease of use and adoption. In TAM, attitudinal determinants-perceived ease of use (PEOU) and perceived usefulness (PU) are tapped through perceived ease of use.

According to Davis [25] in the TAM model, PEOU influences an individual's attitude through two main mechanisms: self-efficacy and instrumentality. His proposed study to validate his model shows that the link between intention to use information systems and perceived usefulness is stronger than perceived ease of use. According to the model, we can expect that the factor that affects the largest number of users is the perceived usefulness of the tool. Therefore, TAM is one of the most influential extensions of Ajzen and Fishbein's Theory of Reasoned Action (TRA) in the literature [33]. TAM replaces TRA's perception of attitudes with two types of technological acceptance (ease of use and usefulness). It also states that the easier the system is to use, the higher the user's perception of effectiveness. In TRA theory, it is suggested that all factors that influence behavior can only indirectly influence behavior by influencing attitudes or subjective norms. A meta-analysis of applications of the Theory of Reasoned Action has shown that the TRA model is a good predictor of individual choices when faced with multiple alternatives [34]. Many authors have refined [35] the initial model in an attempt to find the underlying factors behind potential ease of use and usefulness. TAM thus replaces the TRA attitude determinants of perceived usefulness and ease of use.

In TAM 2, Venkatesh and Davis [36] noted that social influence processes (subjective norms, voluntariness, image) and cognitive instrumental processes (job relevance, output quality, outcome vulnerability) affect perceived usefulness and intention to use. TRA and TAM both have strong behavioral elements that assume that when someone forms an intention to act, they will be able to do so without the assumption, and free to do so without restriction also. New technologies that are constantly evolving are complex. There is uncertainty for decision-makers in the successful adoption of these new technologies when people form attitudes and behavioral intentions in trying out new technologies and learning them. These attitudes and behavioral intentions have a direct impact on behavior when users' attitudes and intentions may be wrong or lack beliefs.

A notable number of empirical studies $[25,33]$ cutting across multiple disciplines have investigated and explored PEOU and PU, the two key factors of adopting a new information technology (IT). It will be interesting to find out how these two factors and expected relationship influence social media adoption. In other words, it is motivating to look at relationships of these factors within the models and thematic contexts influence in these respective studies. Thus, we include these two constructs PEOU and PU in the current study with other independent variables to illustrate how students' concern for PEOU and PU influence their motivation to adopt social media platforms or improve their intention to abandon the platform.

\subsection{TTAT (Technology Threat Avoidance Theory)}

TTAT [26] explains the approach-avoidance discrepancy which was ignored by previous theories. TTAT theorizes that avoidance of a malicious threat is not similar to the adoption of a protection measure. As adoption motivation behaviors are qualitatively diverse, henceforth, the application of previous theory may lead to inconsistent findings.

TTAT has the potential to assist the social media industry in enhancing security awareness and designing efficacious mechanisms to improve students' knowledge towards threats as well as understand how students actively and passively react to threats. Improved awareness also helps to enhance students' adoption motivation and helps to adopt more social media applications without negative outcomes. Hence, TTAT is explored in the current study to provide a better understanding of students' adoption of e-learning motivation by both process research and variance research from a social media perspective. 
TTAT posits that IT threat avoidance behavior can be depicted as a cybernetic process in which the user's goal is to spread the distance between their current privacy concern and the unsafe result [37-39].

Based on these appraisals, they decide which coping appraisal to use to reduce the threat. The key consideration of TTAT is to identify the mirror of user perceptions, motivations, and behaviors during the time of threat avoidance behavior. According to TTAT, users will avoid a social medial application if they believe that the social medial application is a threat and can be avoided by applying a coping appraisal. TTAT suggests that users' threat perceptions are determined by the perceived probability of the threat's occurrence and the perceived severity of the threat's negative outcome [26]. Literature provided evidence TTAT could be integrated with other relevant theoretical frameworks or antecedent variables to give an in-depth understanding of behavior practices [26]. TTAT will offer a comprehensive theoretical underpinning to understand students' concerns regarding risk appraisal in terms of using e-learning with a social medial platform and comprehensively interpret student's threat avoidance behavior. We consider that student's motivation to use e-learning is considered as a coping assessment. Further, we believe that TTAT constructs (threat and coping appraisal) can extensively assess the formation of appraisal of external coping as the basic precondition of TTAT is how a student reacts when a student perceives a threat in terms of using e-learning threat. Thus, taken together, we argue both models that TAM and TTAT can have an impact on students' tendency to use e-learning applications. For example, using e-learning applications could be considered threatening to one's beliefs and moral principles. A student may thus foresee such threats and refrain from using the application to avoid post-motivation behavior. Therefore, we proposed a comprehensive research model incorporating TAM and TTAT to explore students' motivation to use e-learning to fulfil the purpose of the current study.

Thus, based on the above discussion we proposed the following hypotheses and research framework (Figure 1):

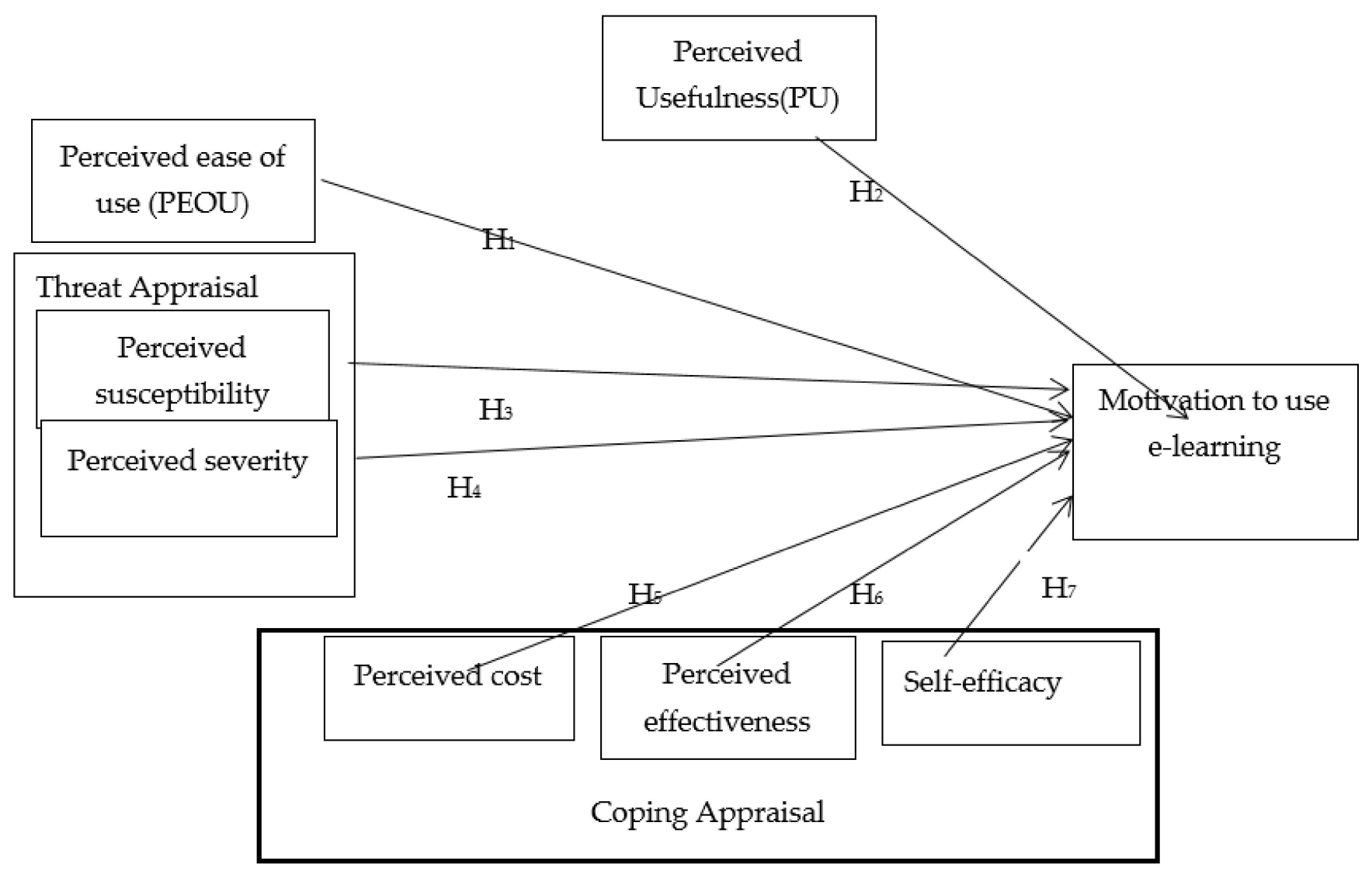

Figure 1. Research framework: technology threat avoidance theory (TTAT). 
Hypotheses 1 (H1). Perceived ease of use has a positive influence on students' motivation to use e-learning with social media.

Hypotheses 2 (H2). Perceived usefulness has a positive influence on students' motivation to use e-learning with social media.

Hypotheses 3 (H3). Perceived susceptibility has a positive influence on users' motivation to use e-learning with social media.

Hypotheses 4 (H4). Perceived severity has a positive influence on users' motivation to use e-learning with social media.

Hypotheses 5 (H5). Perceived cost has a negative influence on users' motivation to use e-learning with social media.

Hypotheses 6 (H6). Perceived effectiveness positively influences users' motivation to use elearning with social media.

Hypotheses 7 (H7). Self-efficacy positively influences users' motivation to use e-learning with social media.

\section{Materials and Methods}

\subsection{Questionnaire Design and Data Collection}

A questionnaire survey was employed to investigate the proposed theoretical framework. A questionnaire was developed with a range of items intended to evaluate each construct of the current study. A preliminary list of measurement items was primarily developed after reviewing the literature regarding TAM and TTAT and motivate behaviors. The instruments used for the current study comprised three sections Appendix A. In the first section, the cover page, the purpose of the study was provided. The second section considered the respondent's demographic information, including their gender, education, and age. The third section contained indicators concerning TAM (9 items), TTAT (21 items), motivation behaviors (4 items).

Threat appraisal comprises two different concerns, perceived severity and perceived susceptibility. Based on the literature [26] we included these two factors in our study. Ten items were used to measure perceived severity and five items were used to measure perceived susceptibility, which is taken from literature. However, we modified items based on our study purpose. Coping appraisal comprises three different concerns, perceived cost, perceived effectiveness, and self-efficacy. Based on the literature [26] we included these three factors in our study.

\subsection{Results}

The current study collected 267 responses. However, 5 responses were considered ineffective due to missing values. Thus, 262 valid responses were used for the final analysis. The details of respondents' demographics are shown in Table 1, and it indicates that respondents differ, respectively, in gender, age, and educational level.

Table 1. Demographics of survey respondents.

\begin{tabular}{cccc}
\hline & Option & Frequency & Percentage (\%) \\
\hline \multirow{2}{*}{ Gender } & Male & 140 & 53.44 \\
& Female & 122 & 46.56 \\
\hline \multirow{2}{*}{ Age } & $18-24$ & 164 & 62.59 \\
& $25-30$ & 98 & 37.41 \\
\hline \multirow{2}{*}{ Educational qualification } & Bachelor & 167 & 63.74 \\
& Associate degree & 55 & 20.99 \\
& Master & 40 & 15.27 \\
\hline
\end{tabular}




\subsection{Instrument Reliability Test}

Reliability analysis was tested using Cronbach's alpha and composite reliability (CR), to measure the model's internal consistency. According to Hair et al. [40], Cronbach's alpha value of the latent factor of 0.7 or above indicates good reliability. Table 2 shows that the Cronbach's alpha of each construct ranged from 0.805 to 0.985 , which is above the recommended value of 0.7 by Hair et al. [40]. According to Hair et al. [40], the composite reliability value of the latent factor of 0.7 or above indicates good reliability. Table 2 shows that the composite reliability of each construct ranged from 0.836 to 0.891 , above the recommended value of 0.7 by Hair et al. [40].

Table 2. The measurement quality evaluation.

\begin{tabular}{cccc}
\hline Construct & Cronbach's Alpha & Composite Reliability & Average Variance Extracted \\
\hline PU & 0.867 & 0.876 & 0.911 \\
PEOU & 0.805 & 0.836 & 0.829 \\
Susceptibility & 0.820 & 0.850 & 0.865 \\
Severity & 0.985 & 0.870 & 0.891 \\
Cost & 0.872 & 0.881 & 0.947 \\
Effectiveness & 0.869 & 0.877 & 0.915 \\
Self-efficacy & 0.886 & 0.891 & 0.974 \\
Motivation & 0.878 & 0.885 & 0.958 \\
\hline
\end{tabular}

\subsection{Convergent Validity}

Convergent validity of the scales was examined by using two standards suggested by Bagozzi and Yi [41]: (1) CR should be above 0.7 and (2) average variance extracted (AVE) of each construct should surpass the variance because of the measurement error of that construct (i.e., AVE should exceed 0.50). Table 2 confirms that the composite reliability of each construct ranged from 0.836 to 0.891 , above the recommended value of 0.7 . It also shows that AVE values of constructs ranged from 0.829 to 0.974 , thus meeting each condition for convergent validity. Thus, all above-mentioned conditions are satisfied and indicate good convergent validity.

\subsection{Discriminant Validity}

To test discriminant validity, Fornell and Larcker [42] recommended that the square root of the AVE of the construct should be greater than the estimated correlation shared between the construct and other constructs in the model. Table 3 shows that the square root of AVE for each construct was greater than the correlation values of the construct, thus meeting the condition for discriminant validity.

Table 3. Correlation of measurement items.

\begin{tabular}{|c|c|c|c|c|c|c|c|c|}
\hline & PU & PEOU & Susceptibility & Severity & Cost & Effectiveness & Self-Efficacy & Motivation \\
\hline PU & 0.954 & & & & & & & \\
\hline PEOU & -0.01 & 0.910 & & & & & & \\
\hline Susceptibility & 0.446 & -0.10 & 0.930 & & & & & \\
\hline Severity & 0.479 & -0.08 & 0.667 & 0.943 & & & & \\
\hline Cost & 0.902 & -0.08 & 0.530 & 0.461 & 0.973 & & & \\
\hline Effectiveness & 0.502 & -0.07 & 0.484 & 0.741 & 0.473 & 0.956 & & \\
\hline Self-efficacy & 0.468 & -0.08 & 0.815 & 0.600 & 0.543 & 0.563 & 0.986 & \\
\hline Motivation & 0.463 & -0.13 & 0.827 & 0.598 & 0.541 & 0.583 & 0.927 & 0.978 \\
\hline
\end{tabular}

\subsection{Tests of the Structural Model}

The summary of the hypothesis tests is presented in Table 4 . The results provide support for the five proposed relationships (i.e., H1, H2, H5, H6, and H7) while the remaining two relationships (i.e., $\mathrm{H} 3$, and $\mathrm{H} 4$ ) are not significant at the 0.05 level of 
significance. Tests of significance for all the paths were performed by using the bootstrap resampling procedure.

Table 4. Result of hypothesis testing.

\begin{tabular}{ccccc}
\hline Hypothesis & Proposed Hypothesis Relationship & Path Coefficients & t-Statistics & Hypothesis Test Results \\
\hline H1 & PU $\rightarrow$ Motivation & 0.365 & 7.101 & Supported \\
H2 & PEOU $\rightarrow$ Motivation & 0.509 & 10.432 & Supported \\
H3 & Susceptibility $\rightarrow$ Motivation & -0.143 & 0.997 & Rejected \\
H4 & Severity $\rightarrow$ Motivation & 0.042 & 0.890 & Rejected \\
H5 & Cost $\rightarrow$ Motivation & 0.080 & 2.112 & Supported \\
H6 & Effectiveness $\rightarrow$ Motivation & 0.149 & 2.301 & Supported \\
H7 & Self-efficacy $\rightarrow$ Motivation & -0.202 & 2.672 & Supported \\
\hline
\end{tabular}

Figure 2 displays the standardized path coefficients, path significances, and variance explained $\left(\mathrm{R}^{2}\right)$ by each path. The variance (R-square scores) from the PLS output is 0.770 motivation to use.

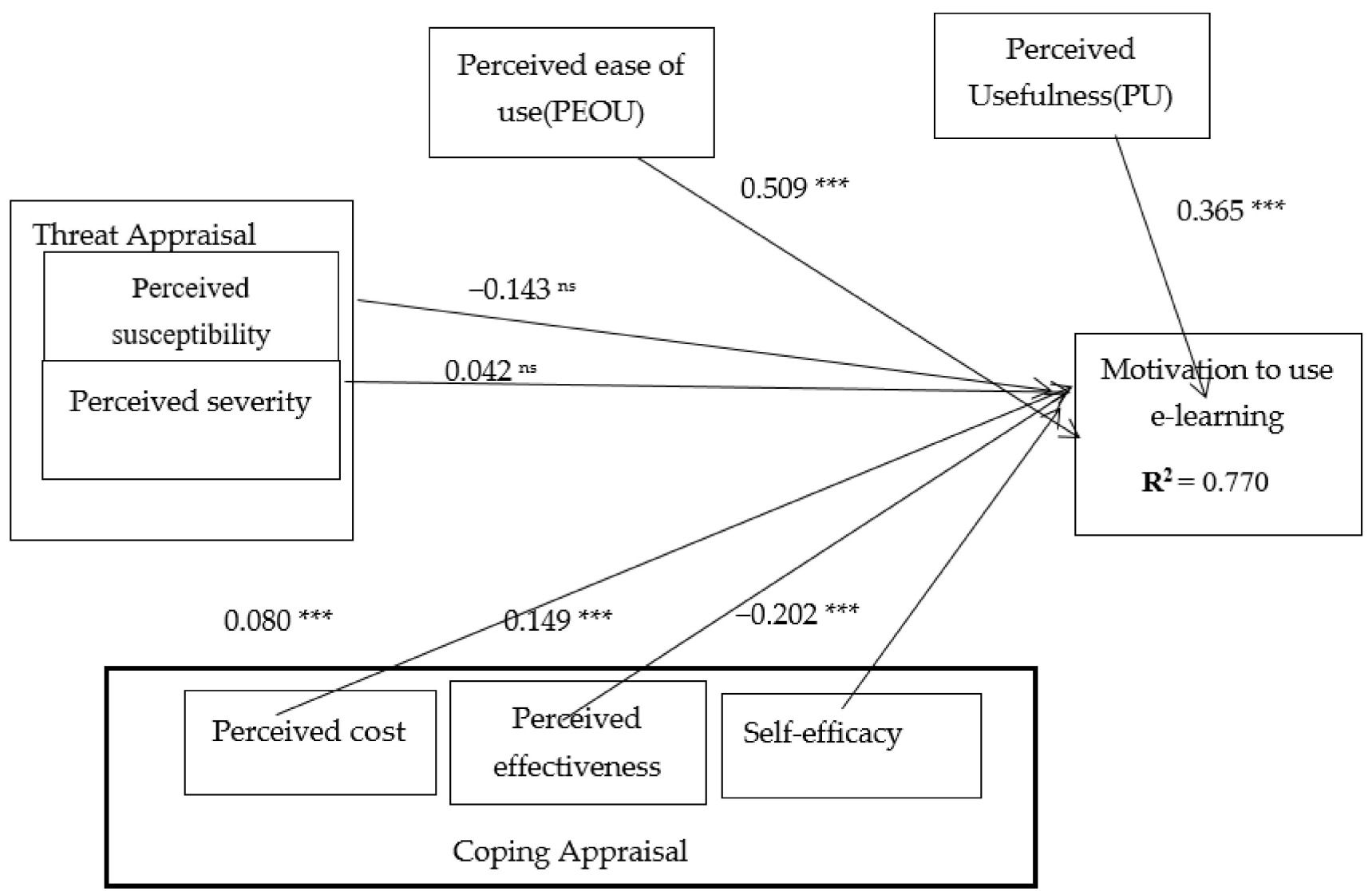

Figure 2. Path analysis result. $p<0.001^{* * *}$, ns not significant at $p<0.05$ level.

\section{Discussion}

As expected, PU and PEOU were found to have a significant positive influence on motivation to use. The findings support the current study that recommends the positive and significant relationship between perceived usefulness and perceived ease of use toward behavioral intention $[43,44]$. From the effect sizes, PEOU is the most dominant factor of behavioral intention, followed by PU. PU accounted for the least variance among the two factors, since individuals have not perceived the importance of e-learning system engagement in their teaching behavioral activities. 
The results of the structural model show that teaching belief factors are key aspects affecting motivation to use the system. The results also demonstrate that teaching belief factor perceived susceptibility has no significant impact on motivation mediated by cues to action. However, perceived severity has a significant effect on cues to action. The unexpected finding could be explained by the fact that the responders have enough teaching promotion knowledge and resources from the online portal. If one's evaluation for the impact and the consequence from a certain type of teaching methodology is highly vulnerable, one may go to the online teaching model and take the help from experts in the field. Therefore, the perceived severity of the responders may not impact significantly on cues to the action of the e-learning system.

The results reported by the current study demonstrated that perceived effectiveness positively influences motivation to adopt e-learning technologies. These results imply that if the perceptions of effectiveness have been amplified the motivation to adopt the technology will be improved and so these will lead to development in the acceptance rate of the e-learning technology. The present findings are constant with previous research [45-47]. According to these findings, both pupils and instructors have to adopt e-learning technologies if they find that these technologies provide the perceptible benefits users claim.

This study investigated the role of self-efficacy in influencing the motivational intention of the students to adopt e-learning for their learning purposes. The results of the study indicate that self-efficacy is an expressive antecedent motivation to use. The university should try to improve the behavior intention of the students through self-efficacy which could lead to improving intention to use e-learning for academic purposes. As self-efficacy plays a critical role in shaping the motivational intention of the user, it may be considered an inherent motivational factor that could assist students to self-regulate their motivation towards the e-learning system used for learning activities. Bandura [48] indicated a better level of self-efficacy outcomes in a progressively active learning process. The instructors and the university authorities should make every attempt to improve the self-efficacy of the students, by providing them inventive projects, internet-based pieces of training which could spark the student's interest in using the internet for their learning purposes.

\section{Conclusions}

As a result, e-learning has become an essential learning method in higher education institutions [5]. It is not intended to replace the traditional classroom setting, but rather to provide a new channel of communication between teachers and students [49]. In the face of the changing environment of e-learning, everyone must be aware that in addition to the connection with the university, these crises and disasters could cause disruptions in the lives of students, teachers, and staff. Therefore, asynchronous learning activities may be more appropriate than synchronous learning activities. In the future, e-learning should increase the applicability and flexibility of course learning.

Hopefully, the COVID-19 threat will soon be a memory of the past. In this case, it is all the more important to go back to the teaching and learning practices that have been in place since the advent of the virus, increasing the importance of e-learning. There may be public health and safety issues in the future, and in recent years, due to natural disasters such as wildfires, floods, hurricanes, and droughts. The potential need for e-learning on campus must become part of the technical capabilities of teachers to teach in the future, as well as to provide sustainable planning for anyone involved in college and university teaching assignments.

The threat of COVID-19 poses some unique challenges for institutions of higher education. All parties involved-students, faculties, and staff-are currently asked to do extraordinary things in terms of course delivery and learning that have not been seen in the lifetime of anyone currently involved [50]. While this situation is stressful, when it is over, educational institutions will have the opportunity to evaluate their ability to implement online instruction to maintain continuity of instruction. E-learning will be sustainable due to the motivation and continuous improvement of instructors. 


\section{Limitations and Future Works}

The current study selected respondents from a single university. Therefore, researchers must be cautious about the generalization of the findings of the study. Thus, future studies could use more than one institute to explore cross-culture findings. Secondly, the current study only received 262 responses. Thus, future studies must include more responses to get more generalization of the findings.

Author Contributions: M.-H.P. contributed to review; research design, data analysis, and manuscript writing. H.-G.H. contributed to conceptualization. Both authors have read and agreed to the published version of the manuscript.

Funding: This research receives no external funding.

Institutional Review Board Statement: Not applicable.

Informed Consent Statement: Not applicable.

Data Availability Statement: Data will be provided on request by the corresponding author.

Conflicts of Interest: The authors declare no conflict of interest.

\section{Appendix A}

Table 1. Measurement items.

\begin{tabular}{|c|c|c|c|}
\hline Construct & Acronym & Definition & Source \\
\hline Perceived severity & $\begin{array}{l}\text { PS1 } \\
\text { PS2 } \\
\text { PS3 } \\
\text { PS4 } \\
\text { PS6 }\end{array}$ & $\begin{array}{l}\text { Online software applications can steal my personal information } \\
\text { from my computer without my knowledge. } \\
\text { Online software applications can violate my privacy. } \\
\text { Online software applications collect personal information about me } \\
\text { that may be used for cybercrime. } \\
\text { Personal information collected by online software applications may } \\
\text { be reused without my authorization. } \\
\text { Online software applications slow down my network speed. } \\
\text { Online software applications can affect some of my computer } \\
\text { programs and interfere with usage. }\end{array}$ & $\begin{array}{l}\text { Liang and } \\
\text { Xue } 2009\end{array}$ \\
\hline Perceived susceptibility & $\begin{array}{l}\text { PS1 } \\
\text { PS2 } \\
\text { PS3 }\end{array}$ & $\begin{array}{l}\text { My computer may be infected by an online software } \\
\text { application virus. } \\
\text { Online software applications are easily accessible. } \\
\text { Online software application is likely to poison my computer. }\end{array}$ & $\begin{array}{l}\text { Liang and } \\
\text { Xue } 2009\end{array}$ \\
\hline Perceived cost & $\begin{array}{l}\text { PC1 } \\
\text { PC2 } \\
\text { PC3 } \\
\text { PC4 }\end{array}$ & $\begin{array}{l}\text { I don't have software applications on my computer because I have } \\
\text { to pay extra for the software. } \\
\text { I don't know how to get the online software application. } \\
\text { Online software applications may cause problems with other } \\
\text { programs on my computer. } \\
\text { It's too much trouble to install online software applications. }\end{array}$ & $\begin{array}{l}\text { Liang and } \\
\text { Xue } 2009\end{array}$ \\
\hline Perceived effectiveness & $\begin{array}{l}\text { PE1 } \\
\text { PE2 } \\
\text { PE3 } \\
\text { PE4 }\end{array}$ & $\begin{array}{l}\text { The use of online software applications allows me to know more } \\
\text { about people. } \\
\text { The use of online software applications has improved my } \\
\text { effectiveness in social messaging and communication with others. } \\
\text { Online software applications make it easier for me to search } \\
\text { for information. } \\
\text { Online software applications can enhance my search for relevant } \\
\text { interests and information more efficiently. }\end{array}$ & $\begin{array}{l}\text { Ramírez-Correa } \\
\text { et al. } 2019\end{array}$ \\
\hline
\end{tabular}


Table 1. Cont.

\begin{tabular}{|c|c|c|c|}
\hline Construct & Acronym & Definition & Source \\
\hline \multirow{7}{*}{ Self-efficacy } & SE1 & $\begin{array}{l}\text { I can operate the online software application according to the } \\
\text { instruction manual (Yuan et al. 2017). }\end{array}$ & \multirow{7}{*}{$\begin{array}{l}\text { Awodoyin } \\
\text { et al. } 2016\end{array}$} \\
\hline & SE2 & $\begin{array}{l}\text { Even if no one can teach me how to use an online software } \\
\text { application, I will continue to use it (Yuan et al. 2017). }\end{array}$ & \\
\hline & SE3 & $\begin{array}{l}\text { I am confident in handling online software applications in my daily } \\
\text { life (Awodoyin et al. 2016). }\end{array}$ & \\
\hline & SE4 & $\begin{array}{l}\text { I am satisfied with using the online software application } \\
\text { (Awodoyin et al. 2016). }\end{array}$ & \\
\hline & SE5 & $\begin{array}{l}\text { I always believe in using online software applications to get my } \\
\text { work done (Awodoyin et al. 2016). }\end{array}$ & \\
\hline & SE6 & $\begin{array}{l}\text { I like to apply what I have learned from online software } \\
\text { applications (Awodoyin et al. 2016). }\end{array}$ & \\
\hline & SE7 & $\begin{array}{l}\text { I like to provide new ideas based on the interaction of online } \\
\text { software applications (Awodoyin et al. 2016). }\end{array}$ & \\
\hline \multirow{4}{*}{$\begin{array}{l}\text { Motivation to use } \\
\text { e-learning }\end{array}$} & INT1 & I think I will use the e-learning application. & \multirow{4}{*}{$\begin{array}{l}\text { Zuiderwijk } \\
\text { et al. } 2015\end{array}$} \\
\hline & INT2 & I recommend using the e-learning application to others. & \\
\hline & INT3 & I will always use learning applications in the future. & \\
\hline & INT4 & Whatsoever the environments, I do not intend to adopt learning & \\
\hline \multirow{6}{*}{$\begin{array}{l}\text { Perceived } \\
\text { usefulness (PU) }\end{array}$} & PU1 & $\begin{array}{l}\text { Using the system in my learning would enable me to accomplish } \\
\text { tasks more quickly. }\end{array}$ & \multirow{6}{*}{ Davis, 1989} \\
\hline & PU2 & Using the system would improve my learning ability performance. & \\
\hline & PU3 & Using the system in my learning would increase my productivity. & \\
\hline & PU4 & Using the system would enhance my effectiveness on the learning. & \\
\hline & PU5 & Using the system would make it easier to do my learning. & \\
\hline & PU6 & I would find the system useful in my learning. & \\
\hline \multirow{6}{*}{$\begin{array}{l}\text { Perceived ease of } \\
\text { use (PEOU) }\end{array}$} & PEOU1 & Learning to operate the system would be easy for me. & \multirow{6}{*}{ Davis, 1989} \\
\hline & PEOU2 & I would find it easy to get the system to do what I want it to do. & \\
\hline & PEOU3 & My interaction with the system would be clear and understandable. & \\
\hline & PEOU4 & I would find the system to be flexible to interact with. & \\
\hline & PEOU5 & It would be easy for me to become skillful at using the system. & \\
\hline & PEOU6 & I would find the system easy to use. & \\
\hline
\end{tabular}

\section{References}

1. Sha'ban, E.; Seyedmohsen, R.; Hamed, J. Impacts of Knowledge Technology on future organizations. IKE 2006, 85-94. [CrossRef]

2. Michelle, P.; Davide, D. An E-learning Web 2.0 Experience. Procedia Soc. Behav. Sci. 2014, 116, 1217-1221. [CrossRef]

3. Abbas, J.; Aman, J.; Mohammad, N.; Shaher, B. The Impact of Social Media on Learning Behavior for Sustainable Education: Evidence of Students from Selected Universities in Pakistan. Sustainability 2021, 11, 1683. [CrossRef]

4. Raghavendra, P.; Hutchinson, C.; Grace, E.; Wood, D.; Newman, L. "I like talking to people on the computer": Outcomes of a home-based intervention to develop social media skills in youth with disabilities living in rural communitie. Res. Dev. Disabil. 2018, 76, 110-123. [CrossRef] [PubMed]

5. Coman, C.; Tîru, L.G.; Meseșan-Schmitz, L.; Stanciu, C.; Bularca, M.C. Online Teaching and Learning in Higher Education during the Coronavirus Pandemic: Students' Perspective. Sustainability 2020, 12, 10367. [CrossRef]

6. Zhang, D.; Zhao, J.L.; Zhou, L.; Nunamaker, J.F., Jr. Can e-learning replace classroom learning? Commun. ACM 2004, 47, 75-79. [CrossRef]

7. Landry, B.J.; Griffeth, R.; Hartman, S. Measuring student perceptions of blackboard using the technology acceptance model. Decis. Sci. J. Innov. Educ. 2006, 4, 87-99. [CrossRef]

8. Wang, C.M.; Reeves, T.C. Synchronous online learning experiences: The perspectives of international students from Taiwan. Educ. Media Int. 2007, 44, 339-356. [CrossRef]

9. Dhawan, S. Online learning: A panacea in the time of COVID-19 crisis. J. Educ. Technol. Syst. 2020, 49, 5-22. [CrossRef]

10. Tommasetti, A.; Singer, P.; Troisi, O.; Maione, G. Extended theory of planned behavior (ETPB): Investigating customers' perception of restaurants' sustainability by testing a structural equation model. Sustainability 2018, 10, 2580. [CrossRef]

11. Isaias, P.; Sampson, D.G.; Ifenthaler, D. Online Teaching and Learning in Higher Education; Springer International Publishing: Berlin/Heidelberg, Germany, 2020; ISBN 978-3-030-48190-2.

12. Arkorful, V.; Abaidoo, N. The role of e-learning, advantages and disadvantages of its adoption in higher education. Int. J. Instr. Technol. Distance Learn. 2015, 12, 29-42. 
13. Wong, A.; Ho, S.; Olusanya, O.; Antonini, M.V.; Lyness, D. The use of social media and online communications in times of pandemic COVID-19. J. Intensive Care Soc. 2020. [CrossRef]

14. Available online: https://www.pewresearch.org/internet/2018/05/31/teens-social-media-technology-2018/ (accessed on 5 July 2021).

15. Available online: https://www.bbc.com/news/technology-42153694 (accessed on 5 July 2021).

16. Available online: https://www.pewresearch.org/internet/fact-sheet/social-media/ (accessed on 5 July 2021).

17. Kumar, V.; Nanda, P. Social media as a tool in higher education: A pedagogical perspective. In Handbook of Research on Diverse Teaching Strategies for the Technology-Rich Classroom; IGI Global, Sharda University: Greater Noida, India, 2020; pp. $239-253$.

18. Laurillard, D. Balancing the media. J. Educ. Telev. 1993, 19, 81-93. [CrossRef]

19. Manu, B.D.; Ying, F.; Oduro, D.; Boateng, S.A. Student engagement and social media in tertiary education: The perception and experience from the Ghanaian public university. Soc. Sci. Humanit. Open 2021, 3, 100100.

20. Available online: https:/ / elearningindustry.com/social-media-in-education-improve-learning (accessed on 5 July 2021).

21. Woolley, R.G. A comment on 'The multipole Hamiltonian for time dependent fields'. J. Phys. B At. Mol. Phys. 1973, 6, L97. [CrossRef]

22. Cuevas, A.; Kohle, F. A case study in using YouTube and Facebook as social media tools in enhancing student centred learning and engagement. In Proceedings of the 3rd International Conference of Education, Research and Innovation (ICERI 2010), Madrid, Spain, 15-17 November 2010; pp. 3596-3601.

23. Ansari, J.A.N.; Khan, N.A. Exploring the role of social media in collaborative learning the new domain of learning. Smart Learn. Environ. 2020, 7, 1-16. [CrossRef]

24. Gonzalez, E.; Mitra, S.; Turel, O. Motivational Impacts on Intent to Use Health-Related Social Media. J. Comput. Inf. Syst. 2020, 60, 136-145. [CrossRef]

25. Davis, F.D.; Bagozzi, R.P.; Warshaw, P.R. User acceptance of computer technology: A comparison of two theoretical models. Manag. Sci. 1989, 35, 982-1003. [CrossRef]

26. Liang, H.; Xue, Y. Avoidance of information technology threats: A theoretical perspective. MIS Q. 2009, 33, 71-90. [CrossRef]

27. Available online: https://www.tourism-review.com/e-learning-has-become-essential-for-schools-news11730 (accessed on 5 July 2021).

28. Perveen, A. Synchronous and asynchronous e-language learning: A case study of virtual university of Pakistan. Open Prax. 2016, 8, 21-39. [CrossRef]

29. Cooke, M.; Buckley, N. Web 2.0, social networks and the future of market research. Int. J. Mark. Res. 2008, 50, 267-292. [CrossRef]

30. Tsao HY, J.; Campbell, C.L.; Sands, S.; Ferraro, C.; Mavrommatis, A.; Lu, S.Q. A machine-learning based approach to measuring constructs through text analysis. Eur. J. Mark. 2020, 54, 511-524. [CrossRef]

31. Friedman, L.W.; Friedman, H. Using social media technologies to enhance online learning. J. Educ. Online 2013, 10, 1-22. [CrossRef]

32. Evans, C. Twitter for teaching: Can social media be used to enhance the process of learning? Br. J. Educ. Technol. 2014, 45, 902-915. [CrossRef]

33. Sarver, V.T. Ajzen and Fishbein's "theory of reasoned action": A critical assessment. J. Theory Soc. Behav. 1983, 13, 155-163. [CrossRef]

34. Sheppard, B.H.; Hartwick, J.; Warshaw, P.R. The theory of reasoned action: A meta-analysis of past research with recommendations for modifications and future research. J. Consum. Res. 1988, 15, 325-343. [CrossRef]

35. Jethro, O.O.; Grace, A.M.; Thomas, A.K. E-learning and its effects on teaching and learning in a global age. Int. J. Acad. Res. Bus. Soc. Sci. 2012, 2, 203.

36. Venkatesh, V.; Davis, F.D. A theoretical extension of the technology acceptance model: Four longitudinal field studies. Manag. Sci. 2000, 46, 186-204. [CrossRef]

37. Carver, C.S.; Scheier, M.F. Control theory: A useful conceptual framework for personality-social, clinical, and health psychology. Psychol. Bull. 1982, 92, 111. [CrossRef]

38. Edwards, S. Trade orientation, distortions and growth in developing countries. J. Dev. Econ. 1992, 39, 31-57. [CrossRef]

39. Carpenter, D.; Young, D.K.; Barrett, P.; McLeod, A.J. Refining technology threat avoidance theory. Commun. Assoc. Inf. Syst. 2019, 44. [CrossRef]

40. Hair, J.F.; Anderson, R.E.; Tatham, R.L.; William, C. Black (1998), Multivariate Data Analysis; Prentice Hall: Upper Saddle River, NJ, USA, 1998.

41. Bagozzi, R.P.; Yi, Y. On the evaluation of structural equation models. J. Acad. Mark. Sci. 1988, 16, 74-94. [CrossRef]

42. Fornell, C.; Larcker, D.F. Structural equation models with unobservable variables and measurement error: Algebra and statistics. J. Mark. Res. 1981, 18, 382-388. [CrossRef]

43. Sun, Y.; Wang, N.; Guo, X.; Peng, Z. Understanding the acceptance of mobile health services: A comparison and integration of alternative models. J. Electron. Commer. Res. 2013, 14, 183-200.

44. Dutta, B.; Peng, M.H.; Sun, S.L. Modeling the adoption of personal health record (PHR) among individual: The effect of health-care technology self-efficacy and gender concern. Libyan J. Med. 2018, 13, 1500349. [CrossRef] [PubMed]

45. Alqurashi, E. Self-efficacy in online learning environments: A literature review. Contemp. Issues Educ. Res. (Online) 2016, 9, 45. [CrossRef] 
46. Al-Gahtani, S.S. Empirical investigation of e-learning acceptance and assimilation: A structural equation model. Appl. Comput. Inform. 2016, 12, 27-50. [CrossRef]

47. Faqih, K.M. Which is more important in e-learning adoption, perceived value or perceived usefulness? Examining the moderating influence of perceived compatibility. In Proceedings of the 4th Global Summit on Education, Kuala Lumpur, Malaysia, 14-15 March 2016

48. Bandura, A. Social cognitive theory and exercise of control over HIV infection. In Preventing AIDS; Springer: Boston, MA, USA, 1994; pp. 25-59.

49. Alawamleh, M.; Al-Twait, L.M.; Al-Saht, G.R. The effect of online learning on communication between instructors and students during Covid-19 pandemic. Asian Educ. Dev. Stud. 2020. [CrossRef]

50. Collazos, C.A.; Fardoun, H.; AlSekait, D.; Pereira, C.S.; Moreira, F. Designing online platforms supporting emotions and awareness. Electronics 2021, 10, 251. [CrossRef] 